\title{
EVALUATION OF SALT TOLERANT GARLIC CULTIVARS BASED ON PHYSIOLOGICAL AND YIELD RESPONSES
}

\author{
A.H.M.M.R. Talukder ${ }^{1 *}$, F. Ahmed ${ }^{1}$, I.M. Ahmed ${ }^{1}$, A.F.M.S. Ahsan ${ }^{1}$ \\ S.N. Mahfuza ${ }^{1}$, N. Mokarroma ${ }^{1}$ and L. Nahar ${ }^{2}$ \\ ${ }^{1}$ Plant Physiology Division, Bangladesh Agricultural Research Institute, Gazipur \\ ${ }^{2}$ Department of Agricultural Botany, Sher-e-Bangla Agricultural University, Dhaka
}

\begin{abstract}
An aggravated salt concentration in soil restricts to intensify the crop productivity. In a salinity tolerance test, five Allium sativum cultivars viz. BARI Rashun-1, BARI Rashun-2, BARI Rashun-3, BARI Rashun-4 and Local (Natore local) were comapared subjecting four level of salt stress viz. $0,4,8$ and $12 \mathrm{dS} \mathrm{m}^{-1}$. Total dry matter (TDM) (g) plant ${ }^{-1}$, bulb yield and yield supporting traits of all cultivars were depressed with successively induced salt. But, TDM productions, yield and yield supporting traits were less degraded in BARI Rashun-4 and BARI Rashun-3 at $12 \mathrm{dSm}^{-1}$ salinity and had a stronger ability to continue constant osmotic potential maintaining the uttermost $\mathrm{K}^{+} / \mathrm{Na}^{+}$ratio. The variety BARI Rashun-4 showed higher activity of antioxidant enzyme and less cell membrane damage at $12 \mathrm{dSm}^{-1}$ salt level. BARI Rashun-3 and BARI Rashun- 4 were considered as a relatively saline tolerant due to higher antioxidant enzyme synthesis, ion homeostasis and less degradation of yield.
\end{abstract}

Keywords: Ascorbate peroxidase, Catalase, Peroxidase, Reactive oxygen species

\section{INTRODUCTION}

Salinity stress is a major inanimate problem that harms the agriculture by deteriorating the productive capacity all over the earth (Arif et al., 2020). It was computed that, almost $20 \%$ soil and even about partly of the earth's total arable land have been damaged by salt (Velmurugan et al., 2020). An extrapolation revealed that, global annual cost would be 27.3 billion US\$ due to hamper of crop manufacture in salt induce soil (Qadir et al., 2014). Therefore, identifications of salt tolerant cultivars would be a great endeavor to feed rising population of the world. Salt has a

\footnotetext{
* Corresponding Author: motiurbari@yahoo.com
} 
detrimental influence on crop intensification and productivity, which is interconnected to metabolic and physiological activities. Owing to the onset of osmotic, ionic and dietary imbalances, metabolic and physiological behaviors of crops are still being disrupted (Gerona et al.,2019). Osmotic stress arises in high salt concentration areas due to $\mathrm{Na}^{+}$and $\mathrm{Cl}^{-}$absorption, which lowers the osmotic potential and inhibits water flow (Hamouda et al., 2016) and thereby causes dehydration that accelarates the osmotic effect to the internal tissue and ions concentration. Plant physiological changes as a result of salinity, including the changes in photosynthetic pigment accumulation, diffusion rate, leaf water potential ability, $\mathrm{K}^{+}, \mathrm{Ca}^{2+}$ and $\mathrm{Mg}^{2+}$ content (Ferdous et al., 2018) and causes a chain of responses like the stomatal closure and therefore a restricted $\mathrm{CO}_{2}$ fixation (Hirdi et al., 2016).

Salinity accelarates the manufacture of reactive oxygen species (ROS), which are highly toxic to the cell and disturb cell redox homeostasis, finally causes oxidative stress. Therefore, plant cells are equipped with well evolved to accumulate the proteolytic and non-proteolytic antioxidant enzymes like catalase (CAT), peroxidase (POD), ascorbate peroxidase (APX) which is strong quencher and scavenger of ROS. Yield and its related traits are inversely related to abiotic stress during plant growth, such as salt (Zorb et al., 2019). Many previous extensive literatures have been expressed that extreme salt stress has a depressing effect on crop morphological performances such as root-shoot length, leaf area, biomass production and among other things. Salinity affects growth differently in different species and to a lesser extent, in different variants within a species. Garlic (Allium sativum) is a highly nutritive crop; it contains large number of important enzymes, antioxidants and vitamins (Mohamed and Akladious, 2014; El-Saadony et al., 2017). Further, Garlic is a valuable spice used in a variety of dishes all over the world for its pungent taste as a seasoning or condiment. Garlic is also used to treat several of diseases, including incurable stomach and intestinal dysentery, typhoid, cholera, and lung diseases according to Ayurvedic and Unani medicine. Garlic clove's aqueous extracts substantially lower cholesterol levels. Garlic cultivars have become more susceptible to abiotic stress as a result of the rapid loss of genetic diversity caused by cultivar substitution. So, the foremost objective of this research was to examine the escalation and physiochemical responses of native and high yielding Allium sativum cultivars to diverse salinity stress and mean while to explore the association among salt tolerance. By understanding physiological aspects of garlic's reaction to salinity stress, researchers may be able to create salt-tolerant cultivars. 


\section{MATERIALS AND METHODS}

Pot house research was carried out following Randomized Complete Block Design (RCBD) with six replications. Clove of Garlic (Allium sativum) varieties viz. BARI Rashun-1, BARI Rashun-2, BARI Rashun-3, BARI Rashun-4 and Natore local were planted in pots on 26 November, 2020. Five cloves of each variety were planted in plastic pots filled with soil and well decomposed farm yard maure at 4:1 volume ratio with a small five perforation system at the pots base for faciliting drainage. Each pot contained approximately $12 \mathrm{~kg}$ soil. Pots soils were nourished by fertilizer according to (FRG, 2018). Before the salt treatments, water and fertilizers were provided to all pots to achieve uniform soil conditions. The tested crops were subjected to different level of salinity stresses viz. 0 (control), 4,8 and $12 \mathrm{dSm}^{-1}$ respectively by adding unpurified sea salt solution. The application of salt solution was started from 30 Days after emergence (DAE) with an increment of 5,10 and15 dSm${ }^{-1}$ for 4,8 and $12 \mathrm{dSm}^{-1}$ salinity level respectively in every 7-10 days intervals and continued up to reach a desire concentration of salinity level. During the crop growing and harvesting period physiological and agronomic parameters were measured.

\section{Physiological parameters}

Chlorophyll synthesis ( $\left.\mathrm{mg} \mathrm{g}^{-1}\right)$ in leaf was measured according to Arnon (1994). In brief, $0.5 \mathrm{~g}$ leaf sample was ruined in $80 \%$ acetone for 48 hours under dark condition. The pigment density was measured with UV-1800 spectrophotometer using wavelength $663 \mathrm{~nm}$ for Chlorophyll $a$ and $645 \mathrm{~nm}$ for Chlorophyll $b$. At 60 days after emergence, $\mathrm{Na}^{+}$and $\mathrm{K}^{+}$ion was measured following the protocol of Rohman et al. (2019). Relative water content was measured with protocol of Ben Ahmed et al. (2011) by using following formula:

$$
\text { Relative water content }(\mathrm{RWC}) \%=\frac{\mathrm{FW}-\mathrm{DW}}{\mathrm{TW}-\mathrm{DW}} \times 100
$$

Where, FW=Fresh weight (g), DW=Dry weight (g), TW=Turgid weight (g)

The level of lipid peroxidation (MDA) was expressed as $\mathrm{nmol} \mathrm{g}^{-1}$ fresh weight and assayed was performed according to $\mathrm{Wu}$ et al. (2003). In briefly, $1.5 \mathrm{ml}$ leaf extract and $2.5 \mathrm{ml}$ reaction solution (5\% Trichloroacetic acid and $0.6 \%$ thiobarbituric acid) was mixed together and heated at $95^{\circ} \mathrm{C}$ for 15 minutes. The absorbance of the supernatant was recorded at $532 \mathrm{~nm}$. The proline content was measured according to method of Bates et al. (1973).

\section{Antioxidant enzyme}

Antioxidant ezymes such as Catalase (CAT), Peroxidase (POD), and Ascorbate peroxidase (APX) were measured according to $\mathrm{Wu}$ et al. (2003). In brief, Catalase activity was measured out in a $3 \mathrm{ml}$ reaction volume containing $2.8 \mathrm{ml}$ of $50 \mathrm{mM}$ Tris- $\mathrm{HCl}$ buffer, $100 \mu \mathrm{l}$ of enzyme extract and $100 \mu \mathrm{l}$ of $300 \mathrm{mM} \mathrm{H}_{2} \mathrm{O}_{2}$ using UV spectrophotometer. Activity was determined at $240 \mathrm{~nm}$ wavelength, which measures 
the decrease in absorbance for 30 second. POD activity was carried out in a $3 \mathrm{ml}$ reaction volume containing $2.7 \mathrm{ml}$ of $50 \mathrm{mM}$ Tris- $\mathrm{HCl}$ buffer, $100 \mu \mathrm{l}$ of enzyme extract and $100 \mu \mathrm{l}$ of $1.5 \%$ Guaicol, $100 \mu \mathrm{l}$ of $300 \mathrm{mM} \mathrm{H}_{2} \mathrm{O}_{2}$ using UV spectrophotometer. Activity was determined at $470 \mathrm{~nm}$ wavelength, which measures the decrease in absorbance for 60 second. APX activity was assayed using $50 \mathrm{mM}$ Tris- $\mathrm{HCl}$ bufferand activity was determined at $290 \mathrm{~nm}$ for 60 second.

\section{Agronomic observation}

Agronomic parameters of Garlic cultivars like total dry matter weight ( $\mathrm{g}$ plant $\left.^{-1}\right)$, yield contributing and bulb yield indices were measured, regardless of salinity level. Total dry mater weight $\left(\mathrm{g}_{\text {plant }}{ }^{-1}\right.$ ) measurement was started from 60 DAE, at 10 days intervals. Plants sample were divided into leaf and bulb categories. The separated parts were dried in an oven for 72 hours at $70^{\circ} \mathrm{C}$ and dry weight was recorded.

\section{Statistic analysis}

Data analysis was performed using computer based software " $R$ " developed by $R$ core team (2019) for interpretation of results. Least significant different values were calculated at 0.05 probability level wherever the F-test was significant.

\section{RESULTS AND DISCUSSION}

\section{Total dry matter (TDM)}

TDM production varied significantly by Garlic cultivars at 70, 85, and 100 days after planting (DAP) and at harvest, regardless of salinity levels (Table 1). At 70 DAP; variety BARI Rashun-2 produced the maximum TDM (4.76 g plant $\left.{ }^{-1}\right)$ at control condition while the local variety produced the minimum $\left(2.60 \mathrm{~g} \mathrm{plant}^{-1}\right)$ at $12 \mathrm{dSm}^{-1}$ salinity. At 85 DAP (7.33 g plant $^{-1}, 90$ DAP (7.56 g plant $\left.{ }^{-1}\right)$ and at harvest $(9.40 \mathrm{~g}$ plant $^{-1}$ ) significantly maximum TDM was produced by the variety BARI Rashun-4 under control (no salinity) condition. TDM of the BARI Rashun-2, BARI Rashun-3 and BARI Rashun-4 was reduced by $43.7,28.8$ and $19.5 \%$, respectively at harvest under $12 \mathrm{dSm}^{-1}$ salinity compared to $8 \mathrm{dSm}^{-1}$. Salinity is an ecological bottleneck to express genetic potentiality of crops. In this study, growths of garlic cultivars were significantly affected by an elevated level of salt stress. This reduction of plant growth and biomass potential under salt stress may be faciliated by reduction of water uptake by plant and excessive salt in plant body with transpiration stream causes wound to cells (Nassar et al., 2020), nutrient uptake (Parvin et al., 2019) and finally inhibiting cell division and elongation (Ahmad et al., 2018). In our stidy, BARI Rashun- 4 showed the best growth at an elevated level of salinity $\left(12 \mathrm{dSm}^{-1}\right)$ through the reduction of minimum dry mater over the control and considered as saline tolerant cultivars. 
Table 1. Total dry matter $\left(\mathrm{g}\right.$ plant $\left.{ }^{-1}\right)$ production by Garlic cultivars under salinity levels

\begin{tabular}{|c|c|c|c|c|c|}
\hline \multirow{2}{*}{ Salinity levels } & \multirow{2}{*}{ Varieties } & \multicolumn{4}{|c|}{ TDM $\left(\right.$ g plant $\left.^{-1}\right)$} \\
\hline & & 70 DAP & 85 DAP & $100 \mathrm{DAP}$ & At harvest \\
\hline \multirow{5}{*}{$0 \mathrm{dSm}^{-1}$} & BARI Rashun-1 & $3.54 \mathrm{i}$ & $4.95 \mathrm{~d}$ & $5.80 \mathrm{~cd}$ & 6.35 ef \\
\hline & BARI Rashun-2 & $4.76 \mathrm{a}$ & $4.65 \mathrm{e}$ & $5.70 \mathrm{c}-\mathrm{e}$ & $8.97 \mathrm{a}$ \\
\hline & BARI Rashun-3 & 3.301 & $6.44 \mathrm{~b}$ & $6.35 \mathrm{~b}$ & $9.12 \mathrm{a}$ \\
\hline & BARI Rashun-4 & $3.81 \mathrm{~h}$ & $7.33 \mathrm{a}$ & $7.56 \mathrm{a}$ & $9.40 \mathrm{a}$ \\
\hline & Natore Local & $2.16 \mathrm{r}$ & $3.41 \mathrm{gh}$ & $5.41 \mathrm{de}$ & $6.74 \mathrm{c}-\mathrm{e}$ \\
\hline \multirow{5}{*}{$4 \mathrm{dSm}^{-1}$} & BARI Rashun-1 & $3.35 \mathrm{j}$ & $4.14 \mathrm{f}$ & $5.48 \mathrm{c}-\mathrm{e}$ & $6.96 \mathrm{~cd}$ \\
\hline & BARI Rashun-2 & $4.63 \mathrm{c}$ & $3.46 \mathrm{gh}$ & $5.25 \mathrm{e}$ & $7.00 \mathrm{c}$ \\
\hline & BARI Rashun-3 & $3.28 \mathrm{~m}$ & $5.69 \mathrm{c}$ & $5.97 \mathrm{bc}$ & $7.96 \mathrm{~b}$ \\
\hline & BARI Rashun-4 & $4.36 \mathrm{~d}$ & $6.51 \mathrm{~b}$ & $5.31 \mathrm{de}$ & $8.12 \mathrm{~b}$ \\
\hline & Natore Local & $2.10 \mathrm{~s}$ & $2.85 \mathrm{j}$ & $5.16 \mathrm{ef}$ & $6.00 \mathrm{fg}$ \\
\hline \multirow{5}{*}{$8 \mathrm{dSm}^{-1}$} & BARI Rashun-1 & $3.28 \mathrm{~m}$ & $3.97 \mathrm{f}$ & $4.70 \mathrm{fg}$ & $5.00 \mathrm{~h}$ \\
\hline & BARI Rashun-2 & $4.68 \mathrm{~b}$ & $3.30 \mathrm{~h}$ & $3.89 \mathrm{~h}$ & $6.70 \mathrm{c}-\mathrm{e}$ \\
\hline & BARI Rashun-3 & $3.33 \mathrm{k}$ & $5.00 \mathrm{~d}$ & $4.69 \mathrm{fg}$ & $6.53 \mathrm{de}$ \\
\hline & BARI Rashun-4 & $4.21 \mathrm{e}$ & $5.51 \mathrm{c}$ & $4.67 \mathrm{fg}$ & $7.08 \mathrm{c}$ \\
\hline & Natore Local & $2.86 \mathrm{p}$ & $1.90 \mathrm{~m}$ & $1.98 \mathrm{k}$ & $2.93 \mathrm{j}$ \\
\hline \multirow{5}{*}{$12 \mathrm{dSm}^{-1}$} & BARI Rashun-1 & $3.00 \mathrm{o}$ & 2.101 & $2.62 \mathrm{j}$ & $2.33 \mathrm{k}$ \\
\hline & BARI Rashun-2 & $4.00 \mathrm{f}$ & $2.62 \mathrm{k}$ & $3.20 \mathrm{i}$ & $3.77 \mathrm{i}$ \\
\hline & BARI Rashun-3 & $3.10 \mathrm{n}$ & $3.11 \mathrm{i}$ & $3.82 \mathrm{~h}$ & $4.65 \mathrm{~h}$ \\
\hline & BARI Rashun-4 & $3.99 \mathrm{~g}$ & $3.50 \mathrm{~g}$ & $4.23 \mathrm{gh}$ & $5.70 \mathrm{~g}$ \\
\hline & Natore Local & $2.60 \mathrm{q}$ & $1.87 \mathrm{~m}$ & $1.93 \mathrm{k}$ & $1.10 \mathrm{k}$ \\
\hline $\operatorname{LSD}_{(0.05)}$ & & 1.08 & 0.20 & 0.54 & 0.44 \\
\hline $\mathrm{CV}(\%)$ & & 3.05 & 2.79 & 6.97 & 4.32 \\
\hline
\end{tabular}

\section{Yield and yield contributing characters}

All yield contributing characters were reduced significantly when the average root zone of crop varieties gradually exceeded to an augmented salinity level (Table 2). The variety BARI Rashun-3 generated the maximum single bulb weight $(5.91 \mathrm{~g})$ at the severe salinity $\left(12 \mathrm{dSm}^{-1}\right)$ followed by the variety BARI Rashun-4. Different salinity levels had an impact on bulb length and diameter. BARI Rashun-4 had the longest bulb length of $22.22 \mathrm{~mm}$ and the largest bulb diameter of $24.98 \mathrm{~mm}$ at $12 \mathrm{ds}$ $\mathrm{m}^{-1}$. With increased salinity, bulb development and yield reduced considerably (Table 1). At $12 \mathrm{ds} \mathrm{m}^{-1}$ salinity level, the bulb yield (g) of five plants was severely reduced (71.6\%) compared to the control. At $8 \mathrm{ds} \mathrm{m}^{-1}$ of salinity, the reduction percentages 
were $68.3,63.3,51.8$ and $41.9 \%$ in case of BARI Rashun-1, BARI Rashun-2, BARI Rashun-3 and BARI Rashun-4, respectively over control. At highest salinity (12 ds $\left.\mathrm{m}^{-1}\right)$; BARI Rashun-3 (60.8\%) and BARI Rashun-4 (61.9\%) showed good tolerance with $\geq 60 \%$ yield reduction over control (Table 2 ). In this study, salinity stress had a significant impact on the agronomic traits of Allium sativum. Single bulb weight, bulb size was significantly affected at an elevated salt stress which may be accredited to inability of the plants to synthesis of phtosynthetic pigments and ionic imbalance. In accordance with present study Ashraf (2009) found that, yield supporting parameters and yield reduction was accelarated due to reductions of leaf chlorophyll concentrations and ionic imbalance.

Table 2. Yield contributing parameters of Garlic varieties under different salinity levels

\begin{tabular}{|c|c|c|c|c|c|}
\hline $\begin{array}{l}\text { Salinity } \\
\text { levels }\end{array}$ & Varieties & $\begin{array}{l}\text { Single bulb } \\
\text { weight }(\mathrm{g})\end{array}$ & $\begin{array}{l}\text { Bulb } \\
\text { length } \\
(\mathrm{mm})\end{array}$ & $\begin{array}{l}\text { Bulb diameter } \\
\qquad(\mathrm{mm})\end{array}$ & $\begin{array}{l}\text { Bulb yield of } \\
\text { five plants }(g)\end{array}$ \\
\hline \multirow{5}{*}{$0 \mathrm{dSm}^{-1}$} & BARI Rashun-1 & $14.96 \mathrm{a}$ & $28.81 \mathrm{a}-\mathrm{c}$ & $33.45 \mathrm{a}$ & $74.8 \mathrm{a}$ \\
\hline & BARI Rashun-2 & $12.74 \mathrm{~b}$ & $31.14 \mathrm{a}$ & $30.46 \mathrm{~b}$ & $63.7 \mathrm{~b}$ \\
\hline & BARI Rashun-3 & $13.33 \mathrm{~b}$ & $30.16 \mathrm{ab}$ & $33.52 \mathrm{a}$ & $66.6 \mathrm{~b}$ \\
\hline & BARI Rashun-4 & $15.56 \mathrm{a}$ & 27.96 b-d & $34.02 \mathrm{a}$ & $77.7 \mathrm{a}$ \\
\hline & Natore Local & $11.11 \mathrm{c}$ & $26.30 \mathrm{c}-\mathrm{f}$ & $30.50 \mathrm{~b}$ & $55.6 \mathrm{c}$ \\
\hline \multirow{5}{*}{$4 \mathrm{dSm}^{-1}$} & BARI Rashun-1 & 7.64 ef & $26.45 \mathrm{c}-\mathrm{e}$ & $26.72 \mathrm{~cd}$ & $33.0 \mathrm{ef}$ \\
\hline & BARI Rashun-2 & $7.36 \mathrm{f}$ & $24.470 \mathrm{e}-\mathrm{g}$ & $25.55 \mathrm{c}-\mathrm{f}$ & $36.8 \mathrm{e}$ \\
\hline & BARI Rashun-3 & $9.54 \mathrm{~d}$ & $26.53 \mathrm{c}-\mathrm{e}$ & $30.65 \mathrm{~b}$ & $38.1 \mathrm{e}$ \\
\hline & BARI Rashun-4 & $9.02 \mathrm{de}$ & $24.13 \mathrm{e}-\mathrm{g}$ & $24.10 \mathrm{e}-\mathrm{g}$ & $47.4 \mathrm{~d}$ \\
\hline & Natore Local & $5.61 \mathrm{gh}$ & $21.87 \mathrm{~g}-\mathrm{i}$ & $23.49 \mathrm{f}-\mathrm{h}$ & $28.1 \mathrm{fg}$ \\
\hline \multirow{5}{*}{$8 \mathrm{dSm}^{-1}$} & BARI Rashun-1 & $4.74 \mathrm{hi}$ & $21.67 \mathrm{~g}-\mathrm{i}$ & $22.89 \mathrm{gh}$ & $23.7 \mathrm{gh}$ \\
\hline & BARI Rashun-2 & $4.68 \mathrm{~h}-\mathrm{j}$ & $25.17 \mathrm{~d}-\mathrm{f}$ & $25.10 \mathrm{j}$ & $23.4 \mathrm{~g}-\mathrm{i}$ \\
\hline & BARI Rashun-3 & $6.42 \mathrm{fg}$ & $25.44 \mathrm{~d}-\mathrm{f}$ & $27.72 \mathrm{c}$ & 32.1 ef \\
\hline & BARI Rashun-4 & $6.60 \mathrm{fg}$ & 20.95 hi & $26.25 \mathrm{c}-\mathrm{e}$ & $45.1 \mathrm{~d}$ \\
\hline & Natore Local & $3.66 \mathrm{i}-\mathrm{k}$ & $19.87 \mathrm{i}$ & $20.31 \mathrm{ij}$ & $18.3 \mathrm{~h}-\mathrm{j}$ \\
\hline \multirow{5}{*}{$12 \mathrm{dSm}^{-1}$} & BARI Rashun-1 & $2.27 \mathrm{k}$ & $20.05 \mathrm{i}$ & $18.52 \mathrm{ij}$ & $11.4 \mathrm{j}$ \\
\hline & BARI Rashun-2 & $3.31 \mathrm{jk}$ & $16.33 \mathrm{j}$ & $20.96 \mathrm{hi}$ & $16.6 \mathrm{ij}$ \\
\hline & BARI Rashun-3 & $5.91 \mathrm{gh}$ & $23.59 \mathrm{f}-\mathrm{h}$ & $22.90 \mathrm{gh}$ & $26.1 \mathrm{fg}$ \\
\hline & BARI Rashun-4 & $5.23 \mathrm{gh}$ & $22.22 \mathrm{~g}-\mathrm{i}$ & $24.98 \mathrm{~d}-\mathrm{g}$ & $29.6 \mathrm{fg}$ \\
\hline & Natore Local & $2.46 \mathrm{k}$ & $15.95 \mathrm{j}$ & $14.68 \mathrm{k}$ & $12.3 \mathrm{j}$ \\
\hline $\mathrm{LSD}_{0.05}$ & & 1.39 & 2.80 & 2.55 & 6.91 \\
\hline CV (\%) & & 5.50 & 7.07 & 6.06 & 11.00 \\
\hline
\end{tabular}




\section{Potassium and Sodium ion in leaf tissue}

With augmented salt stress from 4 to $12 \mathrm{ds} \mathrm{m}^{-1}$, potassium $\left(\mathrm{K}^{+}\right)$concentration increased 10.5, 15.9, 17.5, 18.3 and $14.3 \%$ in BARI Rashun ${ }^{-1}$, BARI Rashun-2, BARI Rashun-3, BARI Rashun-4, and Natore local, respectively (Fig. 1). Regardless of genotypes, the sodium $\left(\mathrm{Na}^{+}\right)$content in leaf tissue was considerably lower in the nonsalt than the salt conditions. In salt stress, elevation was more pronounced in BARI Rashun-1 (158.5 and 34.0\%) and BARI Rashun-2 (145.9 and 63.0\%) at $12 \mathrm{dSm}^{-1}$ salinity than that of $4 \mathrm{dSm}^{-1}$ and $8 \mathrm{dSm}^{-1}$, respectively. The variety BARI Rashun-4 uptake the lowest $\mathrm{Na}^{+}(1090 \mathrm{ppm})$ under $12 \mathrm{dSm}^{-1}$ salinity which were 95.7 and $24.0 \%$ higher than $4 \mathrm{ds} \mathrm{m}^{-1}$ and $8 \mathrm{ds} \mathrm{m}^{-1}$ respectively. At $12 \mathrm{ds} \mathrm{m}^{-1}$ salinity, the highest $\mathrm{K}^{+} / \mathrm{Na}^{+}$was observed in BARI Rashun-4 (4.45) followed by the variety BARI Rashun-3 (4.20) but it was statistically similar with each other. Ion like $\mathrm{Na}^{+}, \mathrm{K}^{+}$and $\mathrm{Ca}^{+}$and their $\mathrm{K}^{+} / \mathrm{Na}^{+}$and $\mathrm{Ca}^{+} / \mathrm{Na}^{+}$ratios are considered an important indicator for tolerance screening (Khorshidi et al., 2009). Tolerant genotypes prevent salt from entering the roots transport less salt to the plant's aerial components. In our study, simultaneously increase $\mathrm{Na}^{+}$and decrease $\mathrm{K}^{+}$in shoots of BARI Rashun-1, BARI rashun- 2 and local cultivar was found at $12 \mathrm{ds} \mathrm{m}^{-1}$ salinity but the changes in $\mathrm{Na}^{+}$and $\mathrm{K}^{+}$were less accentuated in the latter two species that considered as more salttolerant. In earlier literature stated that high levels of $\mathrm{K}^{+}$ion in young expanding tissue are associated with salt tolerance in many plant species (Bandeh-Hagh et al., 2008). In this study, BARI Rashun- 4 showed the considerable $\mathrm{K}^{+} / \mathrm{Na}^{+}$ratio at $12 \mathrm{ds}$ $\mathrm{m}^{-1}$.

\section{Effect of salt stress on physiological activity}

Malondialdehyde increase indicates the rate of lipid peroxidation and oxidative damage. The MDA levels were elevated to 63.2, 64.9, 20.0, 14.0 and 85.2\% in BARI Rashun-1, BARI Rashun-2, BARI Rashun-3, BARI Rashun-4 and Natore local cultivars, respectively, at $12 \mathrm{ds} \mathrm{m}^{-1}$ salt, as compared to unstressed plants (Fig. 2). 

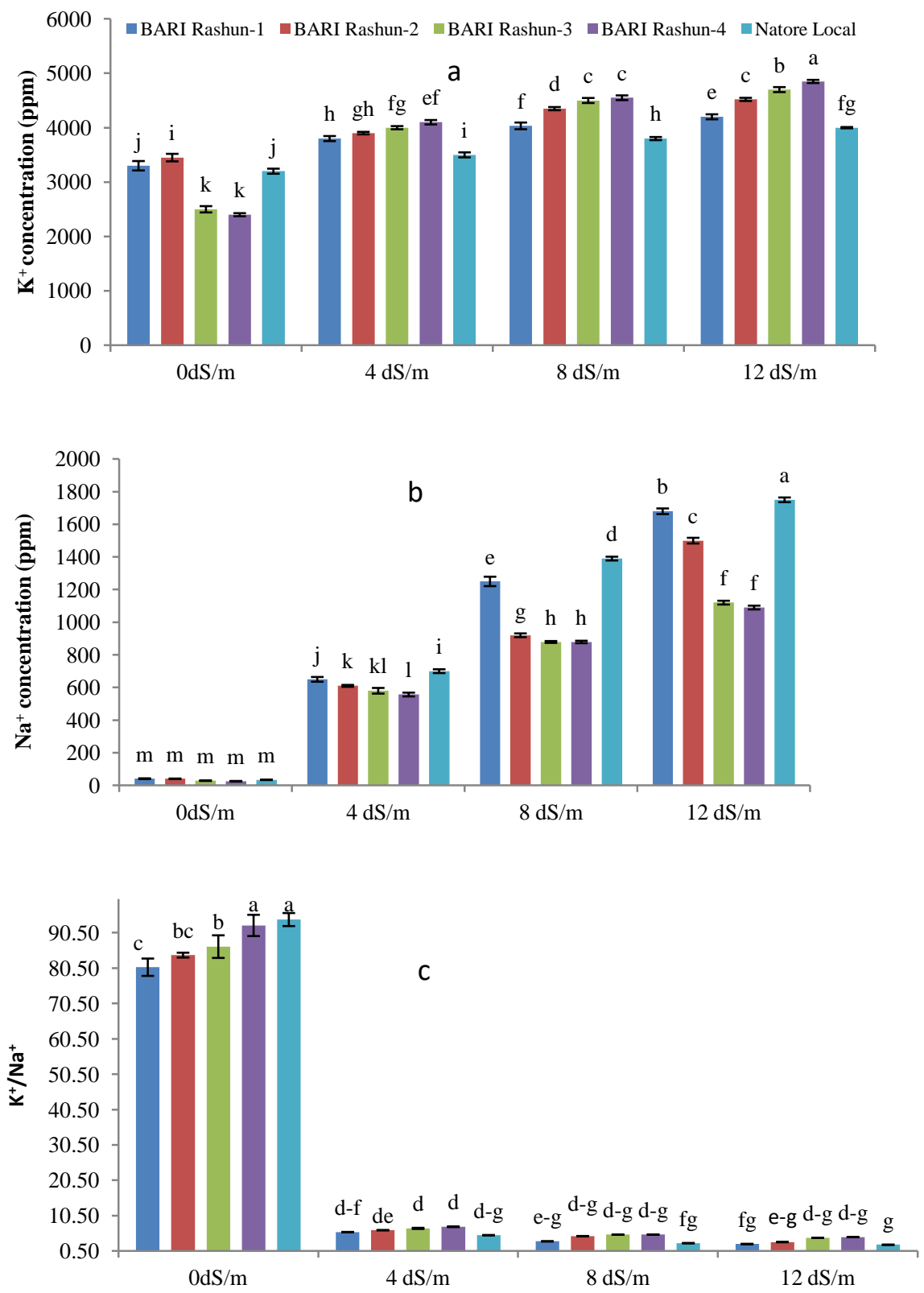

Figure 1. Accumulations of (a) $\mathrm{Na}^{+}$, (b) $\mathrm{K}^{+}$and (c) $\mathrm{K}^{+} / \mathrm{Na}^{+}$ration by Garlic cultivars under varying salinity level 

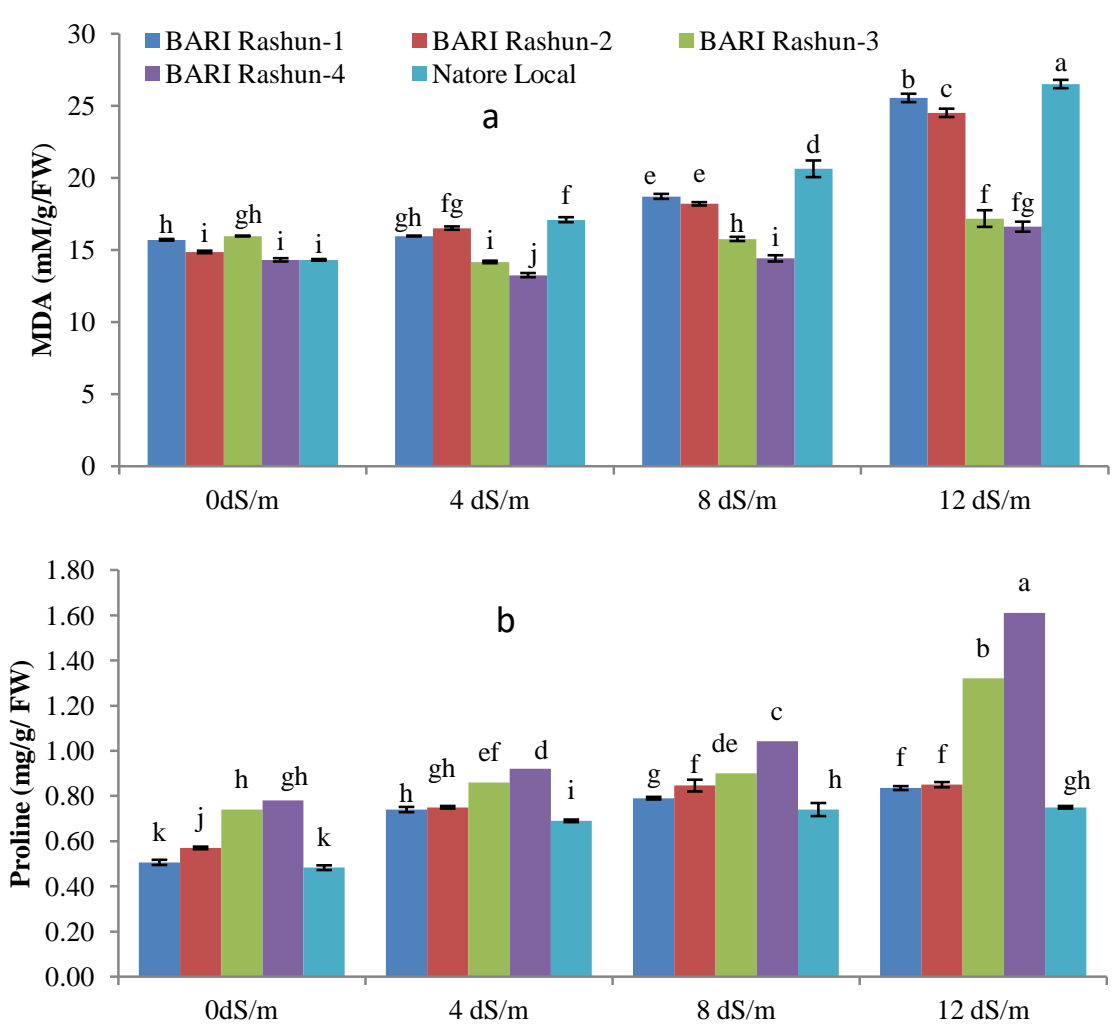

Figure 2. (a) Malondiyldihyde (MDA) and (b) proline level of Garlic cultivars under varying salinity level

The variety BARI Rashun-4 accumulated maximum level of proline, which ranged from $0.78 \mathrm{mg} \mathrm{g}^{-1}$ in the control to $1.60 \mathrm{mg} \mathrm{g}^{-1}$ with $12 \mathrm{ds} \mathrm{m}^{-1}$ of salt. BARI Rashun-4 accumulated 92, 88, 21.2 and 113.3\% higher proline than BARI Rashun-1, BARI Rashun-2, BARI Rashun-3 and Natore local, respectively, at $12 \mathrm{ds} \mathrm{m}^{-1}$ salt stress (Fig. 2). Lipid peroxidation indicated by MDA contents, happening during the oxidation of polyunsaturated fatty acids, can be categorized as an indicator for oxidative damage of stresses (Yin et al., 2011). Our results showed MDA content was increased remarkably under saline conditions. Among the cultivars, BARI Rashun-3 and BARI Rashun-4 had the lowest leaf MDA contents and highest synthesis of proline under $12 \mathrm{ds} \mathrm{m}^{-1}$ saline conditions. Under, $12 \mathrm{dS} \mathrm{m}^{-1}$ salinity, the variety BARI Rashun-1 and BARI Rashun-4 showed 7.40 and $3.70 \%$ higher chlorophyll $a(\mathrm{Chl} a)$ content compared to the control. Although, Chlorophyll $b(\mathrm{Chl}$ b) concentration decreased for all cultivars at $12 \mathrm{dS} \mathrm{m}^{-1}$ salinity over the control (no salinity) but total chlorophyll $(\mathrm{Chl} a+b)$ concentration was increased $6.75 \%$ in 
variety BARI Rashun-1 and 2.66\% in BARI Rashun-4 (Fig. 3). Leaf water potential in stressed plant was comparatively lower than the control plants (Fig.4). Water potentiality of the cultivars was reduced from 1.78 to $6.13 \%$ due to the severity of salt stress. BARI Rashun- 4 had the highest water potentiality, with the lowest (3.50\%) dehydration, whereas Natore local had the lowest, with the highest $(9.13 \%)$ dehydration at $12 \mathrm{dS} \mathrm{m}^{-1}$ salt over control. Our results revealed that, salinity had a significant positive impact on photosynthetic pigment like $\mathrm{Chl}(a)$ and total chlorophyll accumulation in BARI Rashun- 1 and BARI Rashun- 4 at $12 \mathrm{ds} \mathrm{m}^{-1}$ salinity over control. These variations were due to genetic potentiality towards the salt stress. Our results were also similar with previous conducted studies on crop plants like sesame and sunflower by Bazrafshan and Ehsanzadeh (2014) and Rivelli et al. (2010) respectively.
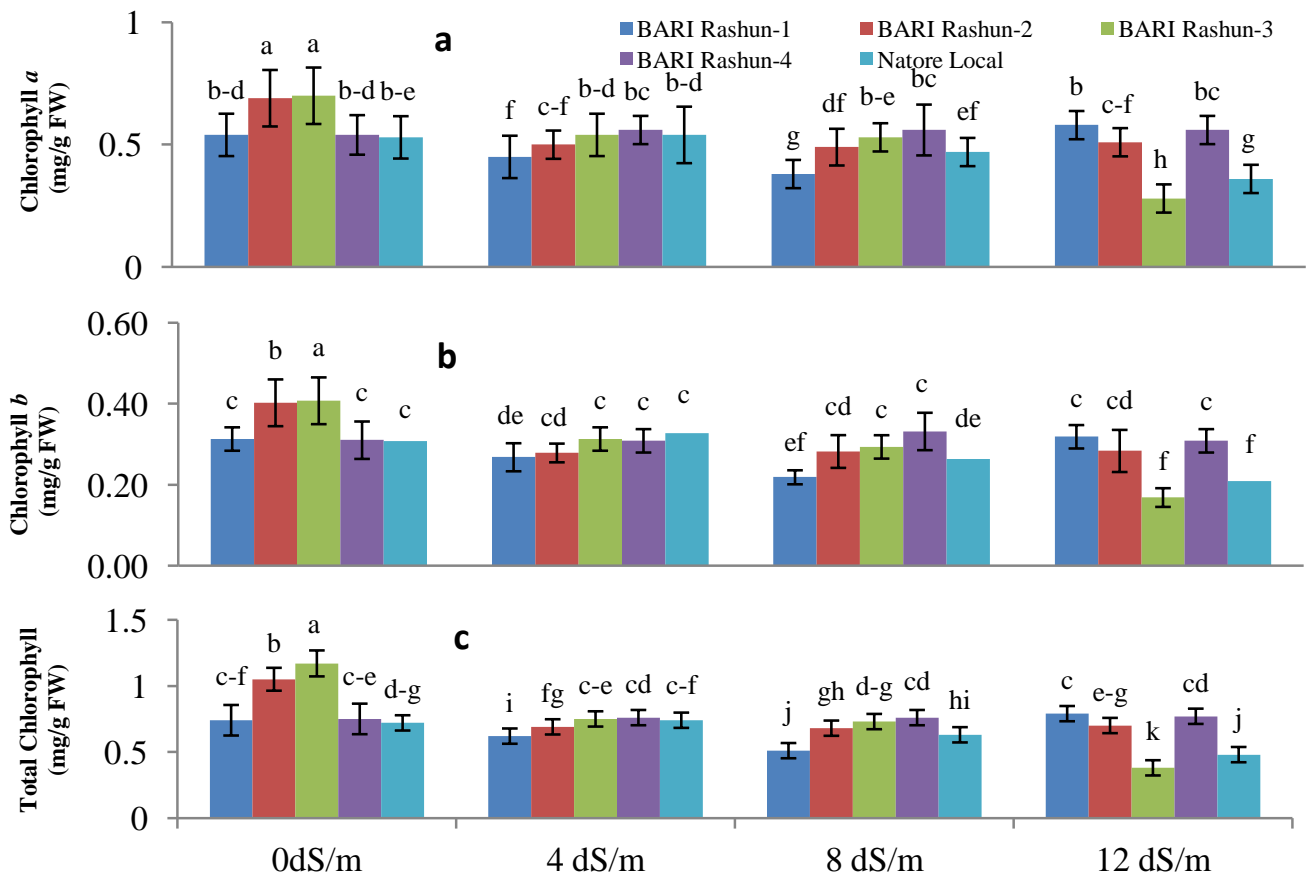

Figure 3. Photosynthetic pigments (a): Chl $a$; (b): Chl $b$; (c): $\operatorname{Chl}(a+b)$ accumulations by Garlic cultivars under varying salinity stress

Effects of salt stress on Antioxidant enzymes activity: In the present study, the activity of antioxidant enzymes like CAT, POD and APX were measured in all tested Garlic cultivars due to investigate the role of these enzymes to salinity tolerance mechanism (Fig.4). 

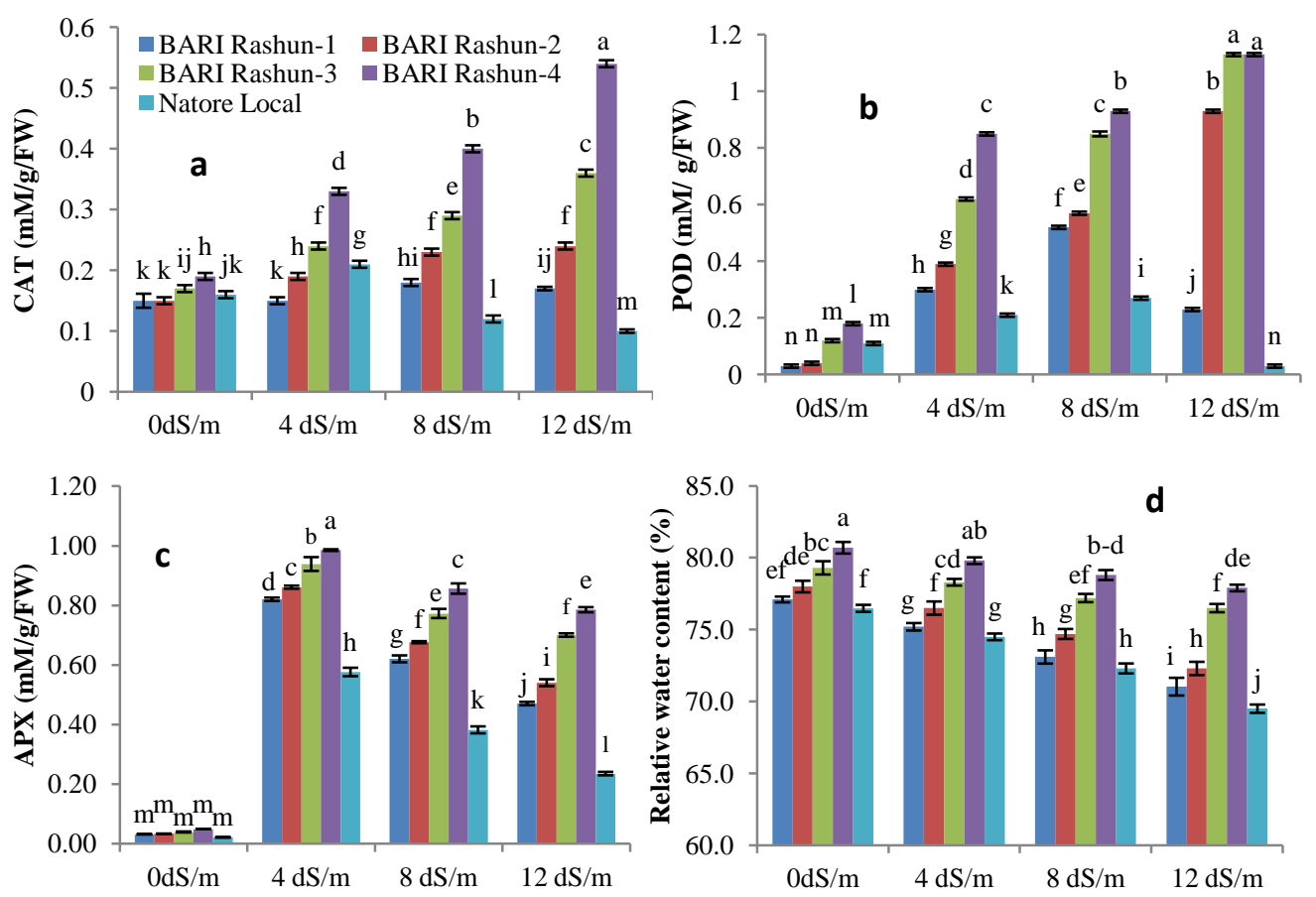

Figure 4. Antioxidant enzymes catalase (a), Peroxidase dismutase (b), Ascorbate peroxidase (c), Relative water content (d) of garlic cultivars under varying salinity stress

Activities of CAT in BARI Rashun-3 and BARI Rashun-4 had reached the maximum level, particularly treated with $12 \mathrm{ds} \mathrm{m}^{-1}$ of salt and was significantly higher than that of other salt stressed, which had increased by 52.7 and $64.8 \%$ compared with control. The variety BARI Rashun-3 and BARI Rashun- 4 accumulated statistically similar and maximum level $\left(1.13 \mathrm{mM} \mathrm{g}^{-1} \mathrm{FW}^{-1}\right)$ of POD at $12 \mathrm{ds} \mathrm{m}^{-1}$ compared to other salt stresses. At $12 \mathrm{ds} \mathrm{m}^{-1}$ salt, APX activities were dexreased in BARI Rashun1(37.5\%); BARI Rashun-2 (22.2\%); BARI Rashun-3 (22.2\%); BARI Rashun-4 (20.0\%), Natore local (33.3\%) in compared to $4 \mathrm{dS} \mathrm{m}^{-1}$ salts. The activity of the APX was minimumly reduced in BARI Rashun-3 and BARI Rashun- 4 at $12 \mathrm{dSm}^{-1}$ salt stress that indicates the higher protective mechanism against ROS than other cultivars. To manage with oxidative damage under stress condition, plants have developed an antioxidant defense mechanism includes the antioxidant enzymes SOD, APX, POD, and CAT (Ali et al., 2017; Polash et al., 2019). Antioxidant enzyme like CAT converts this $\mathrm{H}_{2} \mathrm{O}_{2}$ in water and oxygen and POD also helps to efficiently sift $\mathrm{H}_{2} \mathrm{O}_{2}$. The results of phenotypic and physiological studies and antioxidant defense system showed that BARI Rashun-4 \& BARI Rashun-3 is more tolerant than other cultivars. Based on all phenotypic results of the current study, it is suggested that the tolerance of the Garlic may due to higher concentration of antioxidants enzymes activities viz. POD, CAT, APX and the lower lipid peroxidation level in the leaves. 


\section{CONCLUSION}

Results revealed that higher antioxidant activity like CAT, POD, APX, proline and lower lipid peroxidation as well as higher yield was observed in BARI Rashun-4 and BARI rashun-3 at $12 \mathrm{ds} \mathrm{m}^{-1}$ salinity level. Besides, these varieties also showed the maximum $\mathrm{K}^{+} / \mathrm{Na}^{+}$ratios at higher salinity levels which indicated their tolerancy against salinity.

\section{REFERENCES}

Ahmad, P., Ahanger, M.A, Alyemeni, M.N., Wijaya, L., Alam, P and Ashraf, M. (2018). Mitigation of sodium chloride toxicity in Solanum lycopersicum L. by supplementation of jasmonic acid and nitric oxide. Journal of Plant Interactions, 13: 64-72.

Fertilizer Recommendation Guide. (2018). Bangladesh Agricultural Research Council (BARC), Farmgate, Dhaka 1215. 223p.

Ali, Q., Daud, M.K., Zulqurnain, M. and Ali, S. (2017). Seed priming by sodium nitroprusside improves salt tolerance in wheat (Triticum aestivum L.) by enhancing physiological and biochemical parameters. Plant Physiology and Biochemistry, 119: 50-58.

Arif, Y., Singh, P., Siddiqui, H., Bujguz, A and Hayat, S. (2020). Salinity induced physiological and biochemical changes in plants: An omic approach towards salt stress tolerance. Plant Physiology and Biochemistry, 156: 64-77.

Arnon, D.I. (1949). Copper enzymes in isolated chloroplasts. Polyphenoloxidase in Beta vulgaris. Plant Physiology, 24:1-15.

Ashraf, M. (2009). Biotechnological approach of improving plant salt tolerance using antioxidants as markers. Biotechnology Advances, 27(1): 84-93.

Bandeh-Hagh, A., Toorchi, M., Mohammadi, A., Chaparzadeh, N. Salekdeh G.H. and Kazemnia, H. (2008). Growth and osmotic adjustment of canola genotypes in response to salinity. Journal of Food, Agriculture and Environment, 6: 201-208.

Bates, L.S., Waldren, R.P. and Teare, I.D. (1973). Rapid determination of free proline for water-stress studies. Plant Soil, 39: 205-207.

Bazrafshan, A.H. and Ehsanzadesh, P. (2014). Growth, Photosynthesis and ion of Sesame (Sesamum indicum L.) genotypes in response to Nacl concentration in hydrophonic solution. Photosynthetica, 52:134-147.

Ben Ahmed, C., Magdich, S., Ben Rouina, B., Sensoy, S., Boukhris, M. and Ben Abdullah, F. (2011). Exogenous proline effects on water relations and ions contents in leaves and roots of young olive. Journal of Amino Acids, 40: 565-573.

El-saadony, F.M., Nawar, D.A.S. and Zyada, H.G. (2017). Effect of foliar application with salicylic acid, Garlic extract and proline on growth, yield and leaf anatomy of Pea (Pisum sativum L.) grown under drought stress. Middle East Journal of Applied Science \& Technology, 7(3): 633-650.

Ferdous, J., Mannan, M.A., Haque, M.M., Mamun, M.A.A. and Alam, M.S. (2018). Chlorophyll content, water relation traits and mineral ions accumulation in soybean as influenced by organic amendments under salinity stress. Australian Journal of Crop Science, 12: 1806-1812. 
Gerona, M.E.B., Deocampo, M.P., Egdane, J.A., Ismail, A.M. and Dionisio-Sese, M.L. (2019). Physiological responses of contrasting Rice genotypes to salt stress at reproductive stage. Rice Science, 26: 207-219.

Hamouda, I., Badri, M., Mejri, M., Cruz, C., Siddique, K.H.M. and Hessini, K. (2016). Salt tolerance of Beta macrocarpa is associated with efficient osmotic adjustment and increased apoplastic water content. Plant Biology, 18: 369-375.

Hidri, R., Barea, J.M., Metoui-Ben, M.O., Abdellya, C. and Azconb, R. (2016). Impact of microbial inoculation on biomass accumulation by Sulla carnosa provenances, and in regulating nutrition, physiological and antioxidant activities of this species under nonsaline and saline conditions. Journal of Plant Physiology, 20: 28-41.

Khorshidi, M.B., Yarnia, M. and Hassanpanah, D. (2009). Salinity effect on nutrient accumulation in alfalfa shoots in hydroponic condition. Journal of Food, Agriculture and Environment, 7: 787-790.

Mohamed, H.I. and Akladious, S.A. (2014). Influence of Garlic extract on enzymatic and non enzymatic antioxidants in Soybean plants (Glycine max.) grown under drought stress. Life Science Journal, 11: 46-58.

Nassar, R.M.A., Kamel, H.A., Ghoniem, A.E., Alarcon, J.J., Sekara, A., Ulrichs C. and Abdelhamid, M.T. (2020). Physiological and Anatomical Mechanisms in Wheat to Cope with Salt Stress Induced by Seawater. Plants, 9(2): 237.

Parvin, K., Hasanuzzaman, M., Bhuyan, M.H.M.B., Mohsin, S.M. and Fujita, A.M. (2019). Quercetin mediated salt tolerance in Tomato through the enhancement of plant antioxidant defense and glyoxalase systems. Plants, 8: 247.

Polash, M.A.S., Sakil, M.A. and Hossain, M.A. (2019). Plants responses and their physiological and biochemical defense mechanisms against salinity: A review. Tropical Plant Research, 6: 250-274.

Qadir, M., Quillerou, E., Nangria, V., Murtaza, G., Singh, M. Thomas, R.J., Drechsel, P., Noble, A.D. (2014). Economics of salt-induced land degradation and restoration. Natural Resources Forum, 38: 282-295.

R Core Team, (2019). R: A language and environment for statistical computing. R Foundation for Statistical Computing, Vienna, Austria.

Rivelli, A.R., Maria, S.De., Pizza, S. and Gherbin, P. (2010). Growth and physiological response of hydroponically-grown sunflower as affected by salinity and magnesium levels. Journal of Plant Nutrition, 33:1307-1323.

Rohman, M.M., Islam, M.R., Monsur, M.B., Amiruzzaman, M., Fujita, M. and Hasanuzzaman, M. (2019). Trehalose Protects Maize Plants from Salt Stress and Phosphorus Deficiency. Plants, 8: 568.

Velmurugan, A., Swarnam, P., Subramani, T., Meena, B. and Kaledhonkar, M.J. (2020). Water demand and salinity. Desalination challenges and opportunities. Intech open. doi: 10.5772/intechopen.88095

Wu, F.B., Zhang G.P. and Dominy, P. (2003). Four Barley genotypes respond differently to Cadmium: lipid peroxidation and activities of antioxidant capacity. Environmental and Experimental Botany, 50(1): 67-78.

Yin, H., Xu, L. and Porter, N.A. (2011). Free radical lipid peroxidation: mechanisms and analysis, Chemical Reviews, 111(10): 5944 - 5972.

Zorb, C., Geilfus, C.M. and Dietz, K.J. (2019). Salinity and crop yield. Plant Biology, 1: 31-38. 